turn, suggests that equation (4) could be applied to a strain-softening material, $f$ being interpreted as the proportion of bonds yet to be broken.

During these tests there was some suspicion that a rapid reduction of cell pressure resulted in a softening of the material. This is to be expected, because the compressibility of water is greater than that of the solid skeleton of the soil. Thus, a rapid reduction of cell pressure would cause the water to expand more than the skeleton, forcing the particles apart, and breaking whatever bonds existed. Such an effect may occur around excavations which are dug quickly.

The analysis of normally consolidated slippery-penny-clays may be extended to volumetric effects by assuming that, on average, each turning event annihilates an equal piece of volume. Then

$$
\epsilon_{\mathrm{v}}=A^{*}\left(1-\mathrm{e}^{-a \epsilon}\right)
$$

in an obvious notation. As far as can be ascertained from these preliminary tests, equation (7) is reasonably accurate up to $80 \%$ failure stress.

These tests also suggest that, for the lightly overconsolidated condition, it may prove possible to represent the volumetric strain by

$$
\epsilon_{\mathrm{v}}=A^{*}\left(1-\mathrm{e}^{-a \epsilon}\right)-C^{*}\left(1-\mathrm{e}^{-c \epsilon}\right)
$$

where $A^{*}$ measures a contraction as in equation (7), and where $C^{*}$ measures dilation presumably associatcd with the appearance of micro-voids bctwcen and through domains (Smart, 1969).

Although large strains are involved here, all the strains discussed are, and are intended to be, the ratios of the changes of dimension to the original values of dimension.

The Writer thanks Messrs R. Laird and W. Thomson for much help with the tests.

\title{
REFERENCES
}

Bekker, M. G. (1955). Theory of land locomotion. University of Michigan Press.

Loudon, P. A. (1967). Some deformation characteristics of kaolin. $\mathrm{PhD}$ thesis, University of Cambridge.

Roscoe, K. H. \& Burland, J. B. (1968). On the generalized stress-strain behaviour of 'wet' clay. Engineering plasticity, 535-609. (Heyman, J. \& Leckie, F. A., eds.) Cambridge University Press.

Smart, P. (1966). Particle arrangements in kaolin. Clays Clay Miner. 15, 241-254.

Smart, P. (1967). Soil structure, mechanical properties and electron microscopy. $\mathrm{PhD}$ thesis, University of Cambridge.

Smart, P. (1969). Soil structure in the electron microscope. Structure, solid mechanics and engineering design, 249-255. (Te'eni, M., ed.) London: Wiley-Interscience.

Wroth, C. P. \& Loudon, P. A. (1967). The correlation of strains within a family of triaxial tests on overconsolidated samples of kaolin. Proc. Geotechn. Conf. Oslo 1967 on Shear Strength Properties of Natural Soils and Rocks, 159-163. Oslo: Norwegian Geotechnical Institute.

\section{Use of servo mechanisms for volume change measurement and $K_{0}$ consolidation}

LEWIN, P. I. (1971). Géotechnique 21, No. 3, 259-262. Discussion (1972) 22, No. 1, 186-187.

\section{R. D. Holtz, Swedish Geotechnical Institute, Stockholm}

The Author has presented an interesting improvement over the common method of observing volume changes by burettes during $K_{0}$ consolidation in the triaxial test. However, considerable personal experience with non-hydrostatic consolidation, e.g., Holtz and Krizek (1971), has shown that even though the average cross-sectional area of the specimen was calculated to 
be constant, it could often be observed through the chamber wall that the specimen either bulged or, perhaps worse, alternatively expanded and contracted laterally as the adjustments in the axial load and cell pressure were made. These experiences prompted Krizek and the Writer to term the consolidation 'non-hydrostatic' rather than ' $K_{0}$ ', as originally intended, since no assurance could be given that there had been in fact no lateral strain.

Thus, during investigations of the geotechnical properties of some Swedish clays, a very simple electro-mechnical device whereby the ideal of zero lateral strain can be at least approached during non-hydrostatic consolidation has been constructed. The device, attached to the base of a standard Geonor triaxial cell, is shown in Fig. 1. The dircet current differential transformer is mounted externally because the manufacturer did not recommend immersion at typical cell pressures. The instrument is at present monitored with a voltmeter, and an air pressure regulator connected to the cell water is then adjusted manually to keep the voltmeter as closely as possible at a null value. Sensitivity with the present electronics is of the order of $0.005 \mathrm{~mm}$ and this can be improved by using a more sensitive voltmeter. Axial stress can be applied either incrementally or at a constant strain rate via a loading press; loading rates are determined as usual for a consolidated-drained triaxial test. Automation of the test is currently under development, whereby the cell pressure is automatically increased in response to a very slight movement of the feeler arms.

Professor W. H. Perloff and Research Engineer W. de Groff of Purdue University developed the prototype device, which the Writer first saw in their laboratory in 1970. In addition to a very close tolerance on lateral movement, they have already automated the test.

\section{P. I. Lewin}

Dr Holtz has commented on the difficulties of achieving steady deformation behaviour with an intermittent loading system. The reason for the Writer's specimens not behaving as right circular cylinders is presumably that suggested by Bishop (1958) who drew attention to the need with such systems for avoiding appreciable pore pressure gradients. The Author would agree with the Writer if he is suggesting that intermittent loading systems are basically unsatisfactory. It was for this reason that in 1963 the Author stopped further development of the $K_{0}$ apparatus described in the Note and switched his attention to the simpler approach of consolidating triaxial specimens over a range of anisotropic stress ratios and assessing $K_{0}$ from the stress ratio that would produce zero lateral strain (see Fig. 6, Lewin and Burland, 1970).

\section{REFERENCES}

Bishop, A. W. (1958). Test requirements for measuring the coefficient of earth pressure at rest. Conf. on Earth Pressure Problems, Brussels 1, 2-14.

Holtz, R. D. \& Krizek, R. J. (1971). Effects of stress path and overconsolidation ratio on the shear strength of a kaolin clay. Proc. 5th Reg. Conf. Africa on Soil Mech. Fdn Engng, Luanda.

Lewin, P. I. \& Burland, J. B. (1970). Stress-probe experiments on saturated normally consolidated clay. Géotechnique 20, No. 1, 38-56.

\section{Stresses and displacements in a cross-anisotropic soil}

BARDEN, L. (1963). Géotechnique 13, No. 3, 198-210. Discussion (1970) 20, No. 4, 456-458.

\section{M. Gerrard, CSIRO, Division of Applied Geomechanics, Australia}

In the previous Discussion on this Paper, Raymond (1970) raises some interesting points. However, because the arguments he advances appear to be based on unnecessary restrictions, his conclusions lack generality. 